\section{Microsprinkler Irrigation of Young 'Redblush' Grapefruit Trees Using Reclaimed Water}

\author{
Michael A. Maurer and Frederick S. Davies \\ Horticultural Sciences Department, University of Florida, P.O. Box 110690, \\ Gainesville, FL 32611
}

Additional index words. Citrus paradisi, fertigation, plant nutrients

\begin{abstract}
Two field studies conducted from 1990 to 1991 evaluated the effects of reclaimed water on growth and development of 1- and 2-year-old 'Redblush' grapefruit (Citrus paradisi Macf.) trees on Swingle citrumelo [Citrus paradisi (L.) Osb. $\times$ Poncirus trifoliata (L.) Raf.] rootstock. Treatments were arranged as a3 (water sources) $x 3$ (irrigation levels) factorial at two locations on an Arredondo (well drained) and Kanapaha (poorly drained) fine sand near Gainesville, Fla. Irrigation treatments included 1) reclaimed water, 2) reclaimed water plus fertigation, and 3) well water plus fertigation. The reclaimed water was formulated to simulate that of a sewage treatment plant at Vero Beach, Fla. Irrigation was applied at $20 \%$ soil moisture depletion, or at 19 or $25 \mathrm{~mm} \cdot \mathrm{week}^{-1}$ regardless of rainfall. In both experiments, visual ratings of tree vigor, and measured tree height and trunk diameter, were significantly lower for trees watered with reclaimed water without fertilizer than for the others in both years. Moreover, there was no fourth leaf flush in 1991 with reclaimed water. There was a significant increase in leaf $\mathrm{Na}, \mathrm{Cl}$, and $\mathrm{B}$ concentrations for the reclaimed water and reclaimed water plus fertigation treatments in 1990; however, in 1991 only leaf $B$ concentrations showed a similar trend. In 1991,there were no significant differences in leaf $\mathrm{Cl}$ concentrations. Visual symptoms of $\mathbf{N}$ deficiency were observed by the end of the first season in trees grown with reclaimed water. Irrigation levels generallv did not affect tree growth.
\end{abstract}

Competition for limited water resources is constantly increasing from urban, industrial, and agricultural interests. Inmost states, $\approx 60 \%$ of all water is used for agricultural purposes (Basiouny, 1982). Therefore, interest has increased in using reclaimed water to irrigate various tree crops, including citrus (Kale and Bal, 1987; Koo and Zekri, 1989; Omran et al., 1988; Zekri and Koo, 1990). In 1990, 34\% of the available agricultural water was used to irrigate citrus in Florida (Smajstrlaet al., 1992). In addition, using reclaimed water for citrus irrigation has potential in southern Florida, where increasing population growth not only demands more water, but also requires effective and environmentally safe disposal of reclaimed water.

The primary concern in using reclaimed water for agricultural purposes in many areas is potential heavy metal (Omran et al., 1988) and salinity (Basiouny, 1982) toxicity. Reclaimed water quality, however, varies locally and temporally even within the same treatment facility (Basiouny, 1982). Reclaimed water, compared with well water, had no adverse effects on long-term citrus tree growth in Egypt (On-mm et al., 1988). Similarly, irrigating with reclaimed water increased citrus

Receivedforpublication29July 1992. Accepted for publication 18 June 1993. University of Florida Agricultural Experiment Station journal series no. R-035 14. The cost of publishing this paper was defrayed in part by the payment of page charges. Under postal regulations, this paper therefore must be hereby marked advertisement solely to indicate this fact. growth and yields with no adverse effects compared to citrus grown with well water on the Ridge area of Florida (Koo and Zekri, 1989; Zekri and Koo, 1990). These studies were conducted primarily on mature citrus trees growing on well-drained sandy soils. Soil types and drainage patterns on Florida's east coast differ considerably from those of the central Florida Ridge. High water tables, hardpans, and limited rooting depth in the flatwoods that are prevalent on the east coast present potential waterlogging problems not found in the Ridge area. In addition, few studies (Koo and Zekri, 1989) have been conducted comparing responses of young, nonbeating citrus trees to irrigation with reclaimed water. Our objectives were to determine the effects of microsprinkler irrigation with reclaimed water on growth and development of newly planted citrus trees on well-drained and poorly drained soils.

Two experiments were designed to evaluate irrigating newly planted citrus trees on flatwoods (Expt. 1) and Ridge-type soils (Expt 2) with reclaimed water. Bare-rooted 'Redblush' grapefruit trees on a Swingle citrumelo rootstock $[(\approx 2$ years in the nursery $)$ A. Duda and Sons Citrus Nursery, LaBelle, Fla.] were planted in Apr. 1990. Experiment 1 was planted on double beds [16.75 $\times$ 0.60-0.75 $\times 85 \mathrm{~m}$ (width $\times$ height $\times$ length) $]$ at the Univ. of Florida Horticultural Research Unit near Gainesville. Trees were spaced 3.4 $\mathrm{m}$ within rows and $7.6 \mathrm{~m}$ between rows on each double bed. Soil type was Kanapaha sand (loamy, siliceous, hyperthermic, Grossarenic, Paleaquults) with a loamy or clayey layer starting $\approx 1.2 \mathrm{~m}$ below the soil surface and a water table fluctuating between 0.45 and 1.60 $\mathrm{m}$ from the top of the bed (Marler, 1988). The soil had a volumetric field capacity of $11.3 \%$, a permanent wilting point of $2.0 \%$, and 1.56 gem- mean bulk density (Marler and Davies, 1990).

Experiment 2 was planted at the Univ. of Florida Fifield Farm in Gainesville. Soil type was an Arredondo fine sand (loamy, siliceous, hyperthermic, Grossarenic, Paleudults). The soil had a volumetric field capacity of $10.2 \%$, a permanent wilting point of $1.7 \%$, and 1.66 $\mathrm{g} \cdot \mathrm{m}^{-3}$ mean bulk density. Trees were planted in single rows spaced $4.6 \mathrm{~m}$ within rows and $6.1 \mathrm{~m}$ between rows.

For 3 weeks after planting, trees were irrigated $\approx 2 \mathrm{~h}$ every other day using 38 liters $\cdot \mathrm{h}^{-1}$ $90^{\circ}$ rnicrosprinklers (one per tree) located $1 \mathrm{~m}$ northwest of the trunk (Marler and Davies, 1990). Tree trunks were wrapped with R-11 fiberglass tree wraps (Adaco, Clermont, Fla.) to reduce sprouting and provide freeze protection.

Treatments were arranged as 3 (water sources) x 3 (irrigation levels) factorial experiments with 10 single-tree replications per treatment, based on previous studies (Marler and Davies, 1990). The reclaimed water (nutrient solution) was formulated based on a typical elemental water analysis from a secondary treatment facility in Vero Beach, Fla. (Table 1). The composition of the simulated reclaimed water was changed from 1990 to 1991 to more accurately reflect that of the treatment facility. Treatments included reclaimed water $(\mathrm{RCW})$, reclaimed water plus fertigation $(\mathrm{RCW}+\mathrm{F})$, and well water plus fertigation (WW $+\mathrm{F}$ ). Trees in the RCW treatments received 5, 16, and $27 \mathrm{~g} \mathrm{~N} /$ tree per year in 1990 and 7,20, and $35 \mathrm{~g} \mathrm{~N} /$ tree per year in 1991, respectively, for the three irrigation levels. The RCW $+\mathrm{F}$ and $\mathrm{WW}+\mathrm{F}$ treated trees received 230 and $340 \mathrm{~g} \mathrm{~N} /$ tree per year in 1990 and 1991, respectively, regardless of irrigation level. The 230- and 340-g rates are those currently recommended for 1- and 2-year-old citrus trees in Florida (Koo et al., 1984). In addition, irrigation was applied at $20 \%$ soil moisture depletion - the recommended level (Marler and Davies, 1990). The application rate was 19 and $25 \mathrm{~mm} \cdot$ week $^{-1}$, which simulated frequent irrigations associated with reclaimed water for 31 weeks in 1990 and 39 weeks in 1991. Trees at both locations received 472, 1619, and 2746 liters of water/tree per year in 1990 and731, 2037, and 3454 liters of water/tree per year for Expt. 1; the rate was 687, 2037, and 3454 liters of water/tree per year for Expt. 2 in 1991, respectively. Irrigation at 19 and $25 \mathrm{~mm} \cdot$ week $^{-1}$ was applied three times per week regardless of rainfall, with at least 1 day between irrigations.

Fertigation was applied every 3 weeks (10 times in 1990 and 11 times in 1991). In-line $2 \%$ fixed Dosatron injectors (Dosatron Intl. Clearwater, Fla.) were used to apply liquid fertilizer and formulated RCW. The liquid formulation [8N (4\% $\left.\mathrm{NH} ; 4 \% \quad 4 \% \mathrm{NO}_{3}\right)-0 \mathrm{P}-$ $8 \mathrm{~K}_{2} \mathrm{O}$ ] analysis was supplied from ammonium nitrate and potassium chloride. The injectors 
Production and Culture

Table 1. pH and concentration (in milligrams per liter) of nutrients of well water and simulated reclaimed water (SRW), 1990-91.

\begin{tabular}{|c|c|c|c|c|c|c|c|c|c|c|c|c|c|}
\hline Treatment & $\mathrm{pH}$ & $\mathrm{N}$ & $\mathrm{P}$ & K & $\mathrm{Ca}$ & $\mathrm{Mg}$ & $\mathrm{Na}$ & $\mathrm{Cl}$ & $\mathrm{Cu}$ & $\mathrm{Fe}$ & $\mathrm{Mn}$ & $\mathrm{Zn}$ & B \\
\hline \multicolumn{14}{|l|}{ Well water } \\
\hline Expt. $1^{2}$ & 7.1 & 0.0 & 0.07 & 0.46 & 49.0 & 3.1 & 3.62 & 9.0 & 0.0 & 0.21 & 0.01 & 0.07 & 0.0 \\
\hline Expt. $2^{y}$ & 6.4 & 0.0 & 0.07 & 0.19 & 57.8 & 13.4 & 5.58 & 7.0 & 0.0 & 0.50 & 0.0 & 0.07 & 0.0 \\
\hline \multicolumn{14}{|l|}{$\mathrm{SRW}^{\mathrm{x}}{ }^{\mathrm{T}}$} \\
\hline 1990 & 7.6 & 10.5 & 6.4 & 39.6 & 57.2 & 31.5 & 137 & 115 & 0.01 & .0 .02 & 0.02 & 0.15 & 0.33 \\
\hline 1991 & 8.2 & 10.5 & 6.4 & 15.2 & 57.2 & .24 .0 & 198 & 150 & 0.01 & 0.04 & 0.01 & 0.08 & 0.47 \\
\hline
\end{tabular}

${ }^{2}$ Experiment 1 was conducted on Kanapaha sand (Florida flatwoods).

${ }^{y}$ Experiment 2 was conducted on Arredondo sand (Florida Ridge).

${ }^{\mathrm{x}}$ Composition of the simulated reclaimed water was modified in 1991 to reflect levels obtained in a water treatment facility at Vero Beach, Fla.

also were used to apply the formulated RCW with each irrigation.

Soil moisture was monitored with a Troxler 4300 neutron probe (Troxler, Raleigh, N.C.) three times per week before an irrigation. Four aluminum access tubes were placed $30 \mathrm{~cm}$ from four trees in each of the three irrigation levels. Neutron probe readings were taken at $30-\mathrm{cm}$ depths since $85 \%$ of young citrus tree roots is located from 15 to $45 \mathrm{~cm}$ within this soil (Expt. 1) (Marler and Davies, 1990).

Tree vigor was rated visually at the end of each year, and tree height was measured at planting and again at the end of each growing season. Trunk diameters were measured $\approx 30$ $\mathrm{cm}$ above ground level after planting and after each successive leaf flush, which was monitored weekly through each growing season. An initial composite leaf sample was taken to determine tree nutrient status when the trees came from the nursery. Successive leaf samples were taken at the end of each mature flush when leaves were fully expanded $(\approx 4$ months old). A 10-leaf sample was collected from two trees (one replication) and repeated four times for each treatment. Leaves then were washed in detergent (Dreft; Proctor and Gamble, Cincinnati), rinsed with running tap water and four times in deionized water, dried at $70 \mathrm{C}$ for at least $48 \mathrm{~h}$, and then ground to pass through an $\approx 0.5-\mathrm{mm}$ (40-mesh) screen. Total $\mathrm{N}$ was determined by microKjeldahl procedure (Wolf, 1982) using a rapid flow analyzer (Alpkem Corp., Clackamas, Ore.). Leaf P, K, Na, and B were determined by ashing a 0.5 -g sample in a muffle furnace at $550 \mathrm{C}$ for $8 \mathrm{~h}$. The ash was then brought to $50 \mathrm{ml}$ with $1 \mathrm{NHCl}$ and filtered. Samples were then analyzed on an inductively coupled argon plasma spectrometer (Thermo Jarrell Ash Corp., Boston). A Buchler-Cotlove chloridometer (Buchler Instruments Division, Port Lee, N.J.) was used for $\mathrm{Cl}$ analysis. Water samples were analyzed by the Analytical Research Laboratory, Univ. of Florida, Gainesville.

Both field studies were analyzed as factorial experiments with three water sources and three irrigation levels arranged in a randomized complete block design. The SAS general linear models procedure was used to perform analysis of variance. Regression analyses and orthogonal contrasts also were used to determine trends in the data and to separate means. Regression analysis was based on liters per tree per year in 1990(472,1619, and 2746) and 1991 (731, 2037, and 3454).
Growth and development. Visual ratings of tree growth (data not shown) showed statistical trends similar to trunk diameter measurements. However, trees receiving RCW had smaller canopies and yellowish-green leaves, compared with dark-green leaves of the other treatments. In addition, the oldest mature leaves exhibited visual signs of $\mathrm{N}$ deficiency. In both experiments, $\mathrm{RCW}+\mathrm{F}$ resulted in the largest tree canopies.

Growth flushes occurred around the same time for both experimental sites in 1990, with trees in all treatments having three growth flushes per season. However, at both sites in 1991, three growth flushes occurred on trees irrigated with RCW, but a fourth one occurred on trees in the RCW + F and WW + F treatments (data not shown).

Trees grown with $\mathrm{RCW}+\mathrm{F}$ were tallest, followed, in sequence, by those grown with $\mathrm{WW}+\mathrm{F}$ and RCW in both years in Expt. 1 (Table 2). Tree height in Expt. 2 in 1990 was similar to that in Expt. 1, with RCW + F producing the tallest trees and trees from $\mathrm{RCW}$ and WW + F having similar growth. In 1991, trees grown with $\mathrm{RCW}+\mathrm{F}$ again were taller than those grown with $\mathrm{RCW}$ or WW $+\mathrm{F}$, which grew similarly. In addition, only in

Table 2. Tree height and trunk diameter of young 'Redblush' grapefruit trees as affected by water source (WS) and irrigation level (IL) in 1990 and 1991 (Expt. 1; Kanapaha sand, Florida flatwoods) (Expt. 2; Arredondo sand, Florida Ridge).

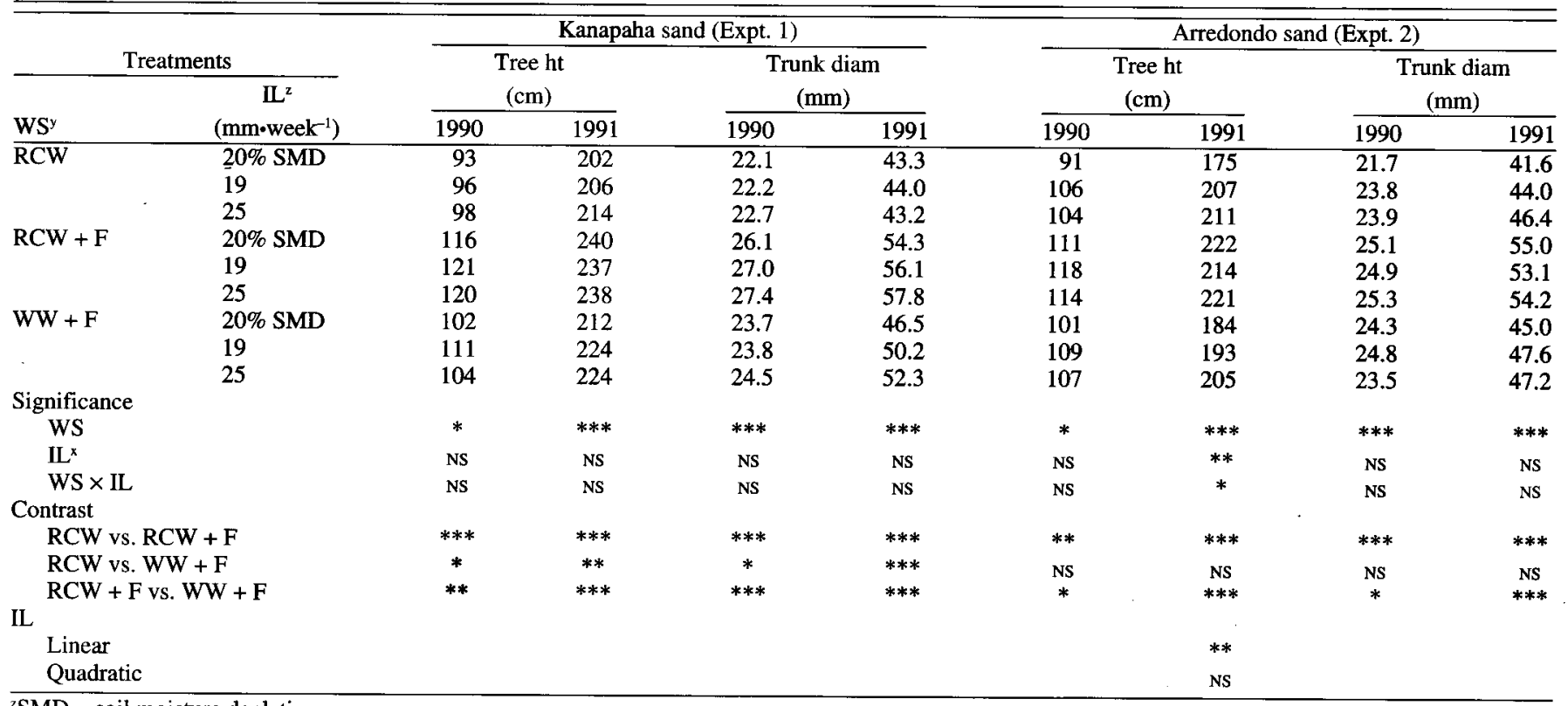

${ }^{\mathrm{z}} \mathrm{SMD}=$ soil moisture depletion.

${ }^{\mathrm{y}} \mathrm{RCW}=$ simulated reclaimed water; $\mathrm{F}=\mathrm{N}-\mathrm{K}$ fertigation; $\mathrm{WW}=$ well water.

${ }^{\times}$Regression analysis was based on liters per tree per year in $1990(472,1619$, and 2746) and 1991 (731, 2037, and 3454).

${ }^{\mathrm{Ns},}{ }^{*},{ }^{* *},{ }^{* * *}$ Nonsignificant or significant at $P \leq 0.05,0.01$, or 0.001 , respectively. 
Expt. 2 in 1991 was there a significant water source $\times$ irrigation level interaction for tree height. The RCW and WW + F treatments led to a significant positive linear response in tree height.

Trunk diameter also differed among all three water sources, with the largest in the $\mathrm{RCW}+\mathrm{F}$ treatment, followed by $\mathrm{WW}+\mathrm{F}$ and RCW in Expt. 1 in both years. In Expt. 2, however, trees in the RCW and $\mathrm{WW}+\mathrm{F}$ treatments responded similarly. There was no significant difference in trunk diameters among irrigation levels for either experiment or year.

Leaf nutrient concentrations. Leaf N concentrations for Expt. 1 were similar in 1990 and 1991, with a significant water source $\times$ irrigation level interaction (Table 3). In Expt. 1 , however, only the WW $+\mathrm{F}$ treatment had a negative linear response to irrigation levels in 1990 and 1991 (Table 3). In addition, leaf N concentrations for Expt. 1 were similar in 1990 and 1991, with significant differences among water source treatments (Table 3 ). In 1990, there was a significant difference among leaf $\mathrm{N}$ concentrations, with the highest in leaves from $\mathrm{WW}+\mathrm{F}$, followed by those from $\mathrm{RCW}+\mathrm{F}$ and RCW. However, in 1991, leaf N levels for RCW were significantly lower than for RCW + F and WW + F. Leaf N concentrations in Expt. 2 also had a significant water source $\mathrm{x}$ irrigation level interaction in 1990 and 1991 (Table 4). In 1990, both the RCW + $\mathrm{F}$ and $\mathrm{WW}+\mathrm{F}$ had a quadratic response in leaf $\mathrm{N}$ to irrigation level (Table 4); however, in 1991, RCW showed a positive and WW + F a negative linear response in leaf $\mathrm{N}$ to irrigation level. Leaf $\mathrm{N}$ levels for Expt. 2, in 1990 and 1991, were highest for WW + F, followed by RCW + F and RCW (Table 4).

Leaf $\mathrm{N}$ was in the optimum range for mature citrus trees in Florida (2.2\% to $2.5 \%$ ) (Koo et al., 1984); however, our values were taken in December from fully expanded leaves from the third growth flush in young trees. Swietlik (1992) observed optimum leaf N averaged from $2.7 \%$ to $2.8 \%$ for young grapefruit trees in Texas, and Willis et al. (1991) found levels as high as 3.0\% for young 'Hamlin' orange [Citrus sinensis (L.) Osb.] trees in Florida. Although leaf N levels following irrigation with RCW alone seemed adequate based on mature-tree leaf $\mathrm{N}$ levels, these trees exhibited visual symptoms of $\mathrm{N}$ deficiency on the mature leaves; also, younger leaves were not as dark green as in the other treatments. The $\mathrm{N}$ deficiency in mature leaves may be due to remobilization of $\mathrm{N}$ from older to younger leaves. This result also suggests that optimum leaf $\mathrm{N}$ ranges are higher for young than mature grapefruit trees.

There was a significant water source $x$ irrigation level interaction for $\mathrm{P}$ concentration in Expt. 1 in 1990 (Table 3). Only RCW had a quadratic response in leaf $\mathrm{P}$ concentrations to irrigation levels. In addition, leaf $P$ concentrations were similar in 1990 and 1991 for Expt. 1, with leaves from RCW having significantly higher leaf $\mathrm{P}$ concentrations than for $\mathrm{RCW}+\mathrm{F}$ and WW + F (Table 3). In Expt. 2 in 1990, leaf $\mathrm{P}$ concentrations were significantly higher for $\mathrm{RCW}$ than for those from $\mathrm{RCW}+\mathrm{F}$ and $\mathrm{WW}$ + F (Table 4). However, in 1991, leaf P con- centrations were significantly lower for RCW $+\mathrm{F}$ compared with RCW and WW + F (Table 4). Elevated P concentrations with RCW treatments may be attributed to reduced tree growth, which causes an accumulation of $\mathrm{P}$ in the leaves, and to the low $\mathrm{N}$ levels. Nitrogen competes with Pin the soil and may decrease its uptake (Smith and Reuther, 1954). Irrigation levels had no effect on leaf $\mathrm{P}$ concentrations.

Leaf $\mathrm{K}$ concentrations responded quadratically to irrigation level in Expt. 1 in 1990 (Table 3). In 1991, RCW had a significantly lower leaf $\mathrm{K}$ concentration than $\mathrm{RCW}+\mathrm{F}$ and WW + F. Leaf K concentrations in Expt. 2 had a significant water source $\times$ irrigation level interaction (Table 4). Irrigation levels in RCW induced a quadratic response in 1990 and a positive linear response in 1991 in leaf $\mathrm{K}$ concentration. In Expt. 2 in 1991, RCW had significantly lower leaf $\mathrm{K}$ concentrations than $\mathrm{RCW}+\mathrm{F}$ and $\mathrm{WW}+\mathrm{F}$ (Table 4). Low leaf K levels in RCW can be attributed to those treatments receiving no additional $\mathrm{K}$ via fertigation. Even though there were significant differences in leaf $\mathrm{K}$ concentrations, the levels were in or above the optimum range (1.2\% to $1.7 \%$ ) for mature citrus trees (Koo et al., 1984). However, as with $\mathrm{N}$, these levels may not be optimum for young grapefruit trees.

Leaf Na concentrations for Expt. 1 in 1990 had a significant water source $x$ irrigation level interaction, with the RCW and $\mathrm{WW}+\mathrm{F}$ having a quadratic and the $\mathrm{RCW}+\mathrm{F}$ a positive linear response to irrigation levels (Table 3).

Table 3. Leaf tissue analysis for young 'Redblush' grapefruit trees (1990-91) as affected by water source (WS) and irrigation level (IL) (Expt. 1; Kanapsha sand, Florida flatwoods). ${ }^{2}$

\begin{tabular}{|c|c|c|c|c|c|c|c|c|c|c|c|c|c|}
\hline \multicolumn{2}{|c|}{ Treatments } & \multicolumn{2}{|c|}{$\mathrm{N}$} & \multicolumn{2}{|c|}{$\mathrm{P}$} & \multicolumn{2}{|c|}{$\mathrm{K}$} & \multicolumn{2}{|c|}{$\mathrm{Na}$} & \multicolumn{2}{|c|}{$\mathrm{Cl}$} & \multicolumn{2}{|c|}{ B } \\
\hline \multirow[b]{2}{*}{$\mathrm{WS}^{\mathrm{x}}$} & \multirow{2}{*}{$\begin{array}{c}\mathrm{IL}^{\mathrm{y}} \\
\left(\mathrm{mm} \cdot \mathrm{week}^{-1}\right)\end{array}$} & \multicolumn{6}{|c|}{ (\% dry wt) } & \multicolumn{6}{|c|}{$\left(\mu \mathrm{g} \cdot \mathrm{g}^{-1}\right.$ dry wt $)$} \\
\hline & & 1990 & 1991 & 1990 & 1991 & 1990 & 1991 & 1990 & 1991 & 1990 & 1991 & 1990 & 1991 \\
\hline \multirow[t]{3}{*}{$\overline{\mathrm{RCW}}$} & $20 \%$ SMD & 2.1 & 2.1 & 0.33 & 0.26 & 1.7 & 1.1 & 310 & 535 & 420 & 195 & 72 & 90 \\
\hline & 19 & 2.3 & 2.3 & 0.47 & 0.27 & 2.2 & 1.4 & 818 & 515 & 805 & 195 & 109 & 107 \\
\hline & 25 & 2.4 & 2.4 & 0.44 & 0.24 & 2.0 & 1.3 & 585 & 598 & 449 & 268 & 94 & 108 \\
\hline \multirow[t]{3}{*}{$\mathrm{RCW}+\mathrm{F}$} & $20 \%$ SMD & 3.2 & 2.7 & 0.19 & 0.14 & 1.8 & 1.3 & 410 & 530 & 210 & 197 & 56 & 77 \\
\hline & 19 & 3.2 & 2.8 & 0.18 & 0.15 & 1.8 & 1.5 & 708 & 538 & 415 & 195 & 78 & 116 \\
\hline & 25 & 3.3 & 2.9 & 0.19 & 0.15 & 1.9 & 1.4 & 828 & 618 & 431 & 217 & 95 & 124 \\
\hline \multirow[t]{3}{*}{$\mathrm{W} W+\mathrm{F}$} & $20 \%$ SMD & 3.9 & 3.2 & 0.20 & 0.18 & 1.8 & 1.5 & 468 & 468 & 132 & 164 & 38 & 43 \\
\hline & 19 & 3.4 & 2.9 & 0.19 & 0.16 & 1.9 & 1.6 & 775 & 498 & 366 & 171 & 43 & 70 \\
\hline & 25 & 3.4 & 2.7 & 0.19 & 0.16 & 1.9 & 1.5 & 370 & 485 & 112 & 165 & 30 & 35 \\
\hline \multicolumn{14}{|c|}{ Significance } \\
\hline \multicolumn{2}{|c|}{ WS } & $* * *$ & $* * *$ & $* * *$ & $* * *$ & NS & $* * *$ & NS & NS & $* * *$ & NS & $* * *$ & $* * *$ \\
\hline \multicolumn{2}{|l|}{$\mathrm{I} \mathrm{L}^{\mathrm{w}}$} & NS & NS & NS & NS & $* *$ & NS & $* * *$ & NS & $* * *$ & NS & $* * *$ & $* * *$ \\
\hline \multicolumn{2}{|c|}{$\mathrm{WS} \times \mathrm{IL}$} & $*$ & $*$ & $*$ & NS & NS & NS & $*$ & NS & NS & NS & $* *$ & * \\
\hline \multicolumn{2}{|l|}{ Contrast } & & & & & & & & & ** & & * & \\
\hline \multicolumn{2}{|c|}{ RCW vs. RCW + F } & $* * *$ & $* * *$ & $* * *$ & $* * *$ & & $* * *$ & & & 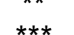 & & $\star * \star *$ & NS \\
\hline \multicolumn{2}{|c|}{$\mathrm{RCW}$ vs. WW + F } & $* * *$ & $* * *$ & $* * *$ & $* * *$ & & $* * *$ & & & * & & $\star \star \star *$ & $* * *$ \\
\hline \multicolumn{2}{|c|}{$\mathrm{RCW}+\mathrm{F}$ vs. $\mathrm{WW}+\mathrm{F}$} & $* *$ & NS & NS & NS & & NS & & & ${ }^{x}$ & & 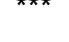 & $* * *$ \\
\hline \multicolumn{9}{|c|}{ IL } & & & & $* *$ & ** \\
\hline \multicolumn{2}{|l|}{ Linear } & & & & & $* *$ & & $* * *$ & & $\begin{array}{l}\mathrm{NS} \\
* * *\end{array}$ & & * & ** \\
\hline \multirow{2}{*}{\multicolumn{14}{|c|}{ Interaction }} \\
\hline & & & & & & & & & & & & & \\
\hline \multicolumn{2}{|l|}{$\mathrm{RCW}$} & NS & NS & $\mathbf{Q}$ & & & & $\mathbf{Q}$ & & & & $\mathbf{Q}$ & NS \\
\hline \multicolumn{2}{|c|}{$\mathrm{RCW}+\mathrm{F}$} & NS & NS & NS & & & & $\overline{\mathrm{L}}$ & & & & $\mathbf{L}$ & $\mathbf{L}$ \\
\hline \multicolumn{2}{|c|}{$\mathrm{W} W+\mathrm{F}$} & $\mathrm{L}$ & $\mathrm{L}$ & NS & & & & Q & & & & NS & $\mathrm{Q}$ \\
\hline
\end{tabular}

${ }^{2}$ Each number represents the mean of five leaves taken from eight trees per treatment. Leaf samples were taken from the third flush of fully expanded leaves in Dec. 1990 and 1991.

'SMD = soil moisture depletion.

${ }^{\mathrm{x}} \mathrm{RCW}=$ simulated reclaimed water; $\mathrm{F}=\mathrm{N}-\mathrm{K}$ fertigation; $\mathrm{WW}=$ well water.

"Regression analysis based on liters per tree per year in 1990 (472, 1619, and 2746) and 1991 (731, 2037, and 3454).

Nonsignificant or significant at $P \leq 0.05,0.01$, or 0.001 , respectively. Linear (L) or quadratic $(\mathrm{Q})$ at $P \leq 0.05$. 
Table 4. Leaf tissue analysis for young 'Redblush' grapefruit trees ( 1990-91) as affected by water source (WS) and irrigation level (IL), Expt. 2 (Arredondo sand, Florida Ridge). ${ }^{2}$

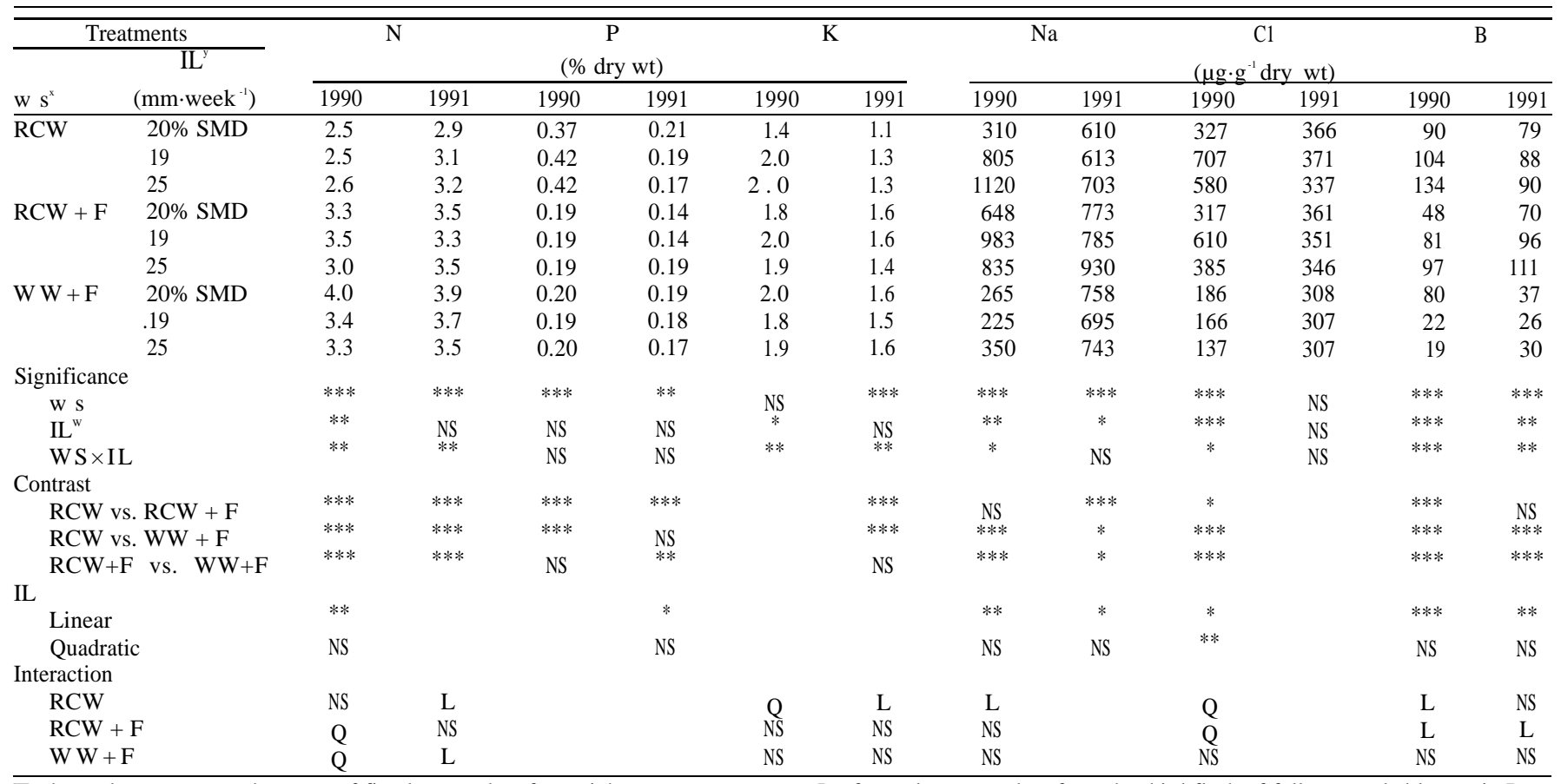

Each number represents the mean of five leaves taken from eight trees per treatment. Leaf samples were taken from the third flush of fully expanded leaves in Dec. 1990 and 1991.

${ }^{y} \mathrm{SMD}=$ soil moisture depletion.

${ }^{\times} \mathrm{RCW}=$ simulated reclaimed water; $\mathrm{F}=\mathrm{N}-\mathrm{K}$ fertigation; $\mathrm{WW}=$ well water.

"Regression analysis was based on liters per tree per year in 1990 (472, 1619, and 2746) and 1991 (731, 2037, and 3454).

Ns, ***,***. Nonsignificmt or significant at $P \leq 0.05,0.01$, or 0.001 , respectively. Linear (L) or quadratic (Q) at $P \leq 0.05$.

In addition, leaf $\mathrm{Na}$ concentrations had a significant quadratic response to irrigation levels. In 1991. the leaf $\mathrm{Na}$ concentration was similar for all treatments. In 1990, Expt. 2 was similar to Expt. 1, with a significant water source $x$ irrigation level interaction, but only RCW had a positive linear response to irrigation levels (Table 4). In 1990, leaf Na concentration in RCW and RCW + F were significantly higher than in WW + F. In 1991, however, RCW + F had a significantly higher leaf $\mathrm{Na}$ concentration, followed by WW $+\mathrm{F}$ and RCW. In addition, in 1990 and 1991, leaf $\mathrm{Na}$ concentrations had a significant positive linear response to irrigation levels.

Leaf $\mathrm{Cl}$ concentration for Expt. 1 in 1990 was highest in RCW, followed by $\mathrm{RCW}+\mathrm{F}$ and $\mathrm{WW}+\mathrm{F}$ (Table 3). Irrigation level produced a significant quadratic response in leaf $\mathrm{Cl}$ concentration in 1990. In 1991, all treatments had similar leaf $\mathrm{Cl}$ concentrations. Results in Expt. 2 were similar to those of Expt. 1 , except that in 1990, there was a significant water source $\times$ irrigation level interaction, with leaf $\mathrm{Cl}$ concentrations in $\mathrm{RCW}$ and $\mathrm{RCW}$ $+\mathrm{F}$ responding quadratically to irrigation level (Table 4). In addition, leaf $\mathrm{Cl}$ concentrations were generally higher in Expt. 2 than in Expt. 1 (Tables 3 and 4).

Leaf B concentrations for Expt. 1 in 1990 had a significant water source $x$ irrigation level interaction, with RCW having a quadratic and $\mathrm{RCW}+\mathrm{F}$ a positive linear response to irrigation levels (Table 3); however, in 1991, RCW + F had a positive linear and WW $+\mathrm{F}$ a quadratic response to irrigation levels. In
1990, leaf B concentrations were significantly higher for RCW, followed by RCW + F and WW + F. However, in 1991, RCW and RCW $+F$ were significantly higher in leaf $B$ concentration than WW + F. In 1990 and 1991, irrigation levels induced a quadratic response in leaf B concentration. In 1990, Expt. 2 had a significant water source $\times$ irrigation level interaction, with RCW and RCW + F showing a positive linear response to irrigation levels (Table 4); however, in 1991, leaf B concentration only in $\mathrm{RCW}+\mathrm{F}$ had a positive linear response to irrigation levels. Leaf B concentrations were significantly higher for RCW, followed by RCW + F and WW + F. In 1991, however, RCW and RCW + F had significantly higher leaf B concentrations than WW + F. Irrigation levels were similar in 1990 and 1991, with a positive linear trend in leaf B concentration. The highest leaf B concentrations were below toxic levels $\left(<250 \mu \mathrm{g} \cdot \mathrm{g}^{-1}\right.$ dry weight) for citrus trees (Koo et al., 1984). Leaf $\mathrm{B}$ concentrations were directly related to the amount of B applied through the reclaimed water.

Even though leaf nutrient concentrations often show a significant water source $x$ irrigation level interaction, especially for $\mathrm{N}$ and $\mathrm{B}$, the nutrient levels were within or above the optimum range, but below the toxic range, and, thus, are not important from a practical standpoint (Koo et al., 1984; Reuther and Smith, 1954).

In summary, field growth of young 'Redblush' grapefruit trees for the first 2 years was not adversely affected by irrigation with reclaimed water, provided that adequate fertilizer was applied. Reclaimed water alone, however, did not provide adequate nutrients for tree growth. Reclaimed water similarly affected trees growing in Kanapaha and Arredondo soils. No deleterious effects on tree growth and development occurred due to the presence of $\mathrm{Na}, \mathrm{Cl}$, or $\mathrm{B}$ in the reclaimed water.

Using reclaimed water to irrigate young citrus trees holds great potential even in poorly drained flatwood areas of Florida, provided the reclaimed water is supplemented with fertilization. Moreover, $\mathrm{Na}, \mathrm{Cl}$, and $\mathrm{B}$ levels in the water should be monitored to prevent possible adverse effects on growth of such trees.

\section{Literature Cited}

Basiouny, F.M. 1982. Wastewater irrigation of fruit trees. Biocycle 23(2):51-53.

Kale, C.K. and A.S. Bal. 1987. Reuse of stabilization pond effluent for Citrus reticulate (orange), forest and road verge plants. Water Sci. Technol. 19(12):307-315.

Koo, R. C.J., C.A. Anderson, I. Stewart, D.P.H. Tucker, D.V. Calvert, and H.K. Wutscher. 1984. Recommended fertilizers and nutritional sprays for citrus. Florida Agr. Expt. Sta. Bul. 536D.

Koo, R.C.J. and M. Zekri. 1989. Citrus irrigation with reclaimed municipal wastewater. Proc. Fla. State Hort. Soc. 102:51-56.

Marler, T.E. 1988. Growth of young 'Hamlin' orange trees as influenced by microsprinkler irrigation, fertilization and nursery tree type. $\mathrm{PhD}$ Diss., Univ. of Florida, Gainesville. (Abstr. 8923588) 
Marler, T.E. and F.S. Davies. 1990. Microsprinkler irrigation and growth of young 'Hamlin' orange trees. J. Amer. Soc. Hort. Sci. 115:45-51.

Omran, M. S., T.M. Waly, E.M. Abd Elnaim, and B.M.B. El Nashar. 1988. Effect of sewage irrigation on yield, tree components and heavy metals accumulation in navel orange trees. Biological Wastes 23:17-24.

Reuther, W. and P. Smith. 1954. Leaf analysis of citrus, p. 257-294. In: N.F.Childers (cd.). Fruit nutrition. Horticultural Publications, Rutgers Univ., New Brunswick, N.J.
Smajstrla, A. G., D.S. Harrison, D.Z. Haman, and F.S. Zazueta. 1992. Irrigation acreage in Florida. Florida Coop. Ext. Serv. Circ. 1030. Univ. of Florida Press, Gainesville.

Smith P. and W. Reuther. 1954. Citrus nutrition, p. 223-256. In: N.F. Childers (cd.). Fruit nutrition.

Horticultural publications, Rutgers Univ., New Brunswick, N.J.

Swietlik, D. 1992. Yield, growth, and mineral nutrition of young 'Ray Ruby' grapefruit trees under trickle or flood irrigation and various nitrogen rates. J. Amer. Soc. Hort. Sci. 117:22-27.
Willis, L. E., F.S. Davies, and D.A. Graetz. 1991. Fertigation and growth of young 'Hamlin' orange trees in Florida. HortScience 26: 106109.

Wolf, B. 1982. A comprehensive system of leaf analysis and its use for diagnosing crop nutrient status. Commun. Soil Sci. Plant Anal. 13:10351059 .

Zekri, M. and R.C.J. Koo. 1990. Effects of reclaimed water on leaf and soil mineral composition and fruit quality of citrus. Proc. Fla. State Hort. Soc. 103:38-41. 